\title{
Protonation and Energetical Investigations of Calix [4]-cyclen-benzo-crown-6 and Its Complexes with Zinc and Copper
}

\author{
Thanaporn Boonchoo, Buncha Pulpoka, and Vithaya Ruangpornvisuti* \\ Department of Chemistry, Faculty of Science, Chulalongkorn Liviversity. Bangkok 10330, Thailand \\ Received Februay /3, 2004
}

Protonation constants of calix[4]-cyclen-benzo-crown-6, $\mathbf{L}$ in $1 \times 10^{2} \mathrm{M} \mathrm{Bu}_{4} \mathrm{NCF}_{3} \mathrm{SO}_{3}$ in $40 \% \mathrm{CH}_{2} \mathrm{Cl}_{2}$ / $\mathrm{CH}_{3} \mathrm{OH}$ at $25^{\circ} \mathrm{C}$ determined by potentiometric titration are $\log \mathrm{K}_{1}=10.9 \mathrm{l}, \log \mathrm{K}_{2}=10.30, \log \mathrm{K}_{3}=6.24$ and $\log \mathrm{K}_{4}=2.55$. Stability constants for the receptor $\mathbf{L}$ complexes with $\mathrm{Cu}(\mathrm{II})$ and $\mathrm{Zn}(\mathrm{II})$ in $\mathrm{I} \times 10^{2} \mathrm{M}$ $\mathrm{Bu}_{4} \mathrm{NCF}_{3} \mathrm{SO}_{3}$ in $40 \% \mathrm{CH}_{2} \mathrm{Cl}_{2} / \mathrm{CH}_{3} \mathrm{OH}$ at $25^{\circ} \mathrm{C}$ were determined by UV-VIS spectrometric titration. Stability constants of the $\mathrm{CuL}$ and $\mathrm{ZnL}$ complexes as $\log \beta$ are 4.37 and 3.45, respectively. Stabilization energies for protonations of receptor $\mathbf{L}$, derived from ab initio l lartree-Fock method with 6-31G basis set, are $\Delta \mathrm{E}_{1}--290.1$, $\Delta \mathrm{E}_{2}--205.0, \Delta \mathrm{E}_{3}--124.9$ and $\Delta \mathrm{E}_{4}--26.9 \mathrm{kcal} / \mathrm{mol}$ and complexation energy of $\mathrm{ZnL}$ complex is -370.3 $\mathrm{kcal} / \mathrm{mol}$.

Key Words : Cyclen, Calixarene, Complexation, Protonation

\section{Introduction}

Since the last decade, calixarenes have received more attention from supramolecular chemists for their intriguing structures and versatile complexation ability. ${ }^{1-4}$ Particularly, $p$-tert-butylcalix[4]arenes have widely attracted many researchers as very useful building blocks for preparing receptors for cations, anions and neutral molecules. Chemical modifications at the lower rim of p-fert-butylcalix[4]arene by alkylation of the phenolic groups with ester," amide," ketone, ${ }^{7}$ carboxylic acid. ${ }^{8}$ hydroxamic, ${ }^{9}$ pyridine, ${ }^{10}$ pyridyl and bipyridyl, alkyl thioether ${ }^{\prime \prime}$ and phosphinite ${ }^{\prime 2}$ functioning pendant groups have been described and their metal complexing properties such as binding ability, ionophoric behaviors and complexation stability have been investigated. Arnaud-Neu et al. have reported the study of acid-base characteristics of calixarene carboxylates, ${ }^{13}$ calixarenecrown- $6^{14}$ and alkyl calixaryl ester and ketones ${ }^{15}$ and their complexation properties towards alkali, alkaline earth metal ions by potentiometric titrations. The calixarene carboxylates were also examined for their complexation with lanthanide metals. ${ }^{16}$ The potentiometric titration technique was demonstrated to give accurate equilibrium constants for each metal complexes and can thus determine the selectivity of each calix[4]arene derivatives towards metal ions. Selective recognition of a receptor to metal ions depends on the ring size and number of donor atoms in the receptor, the cyclen (aza and oxo) derivative of calix[4]arene as receptor $\mathbf{L}$ (shown in Figure I) is, therefore, of interest for investigation of its complexation with metal cations and protonation.

\section{Experimental Section}

Potentiometric Measurements: The protonation constants

Corresponding Author. Tel: 166-2218-7644; rax: 66-22541309; e-mail: vithaya.rochula.ac.th

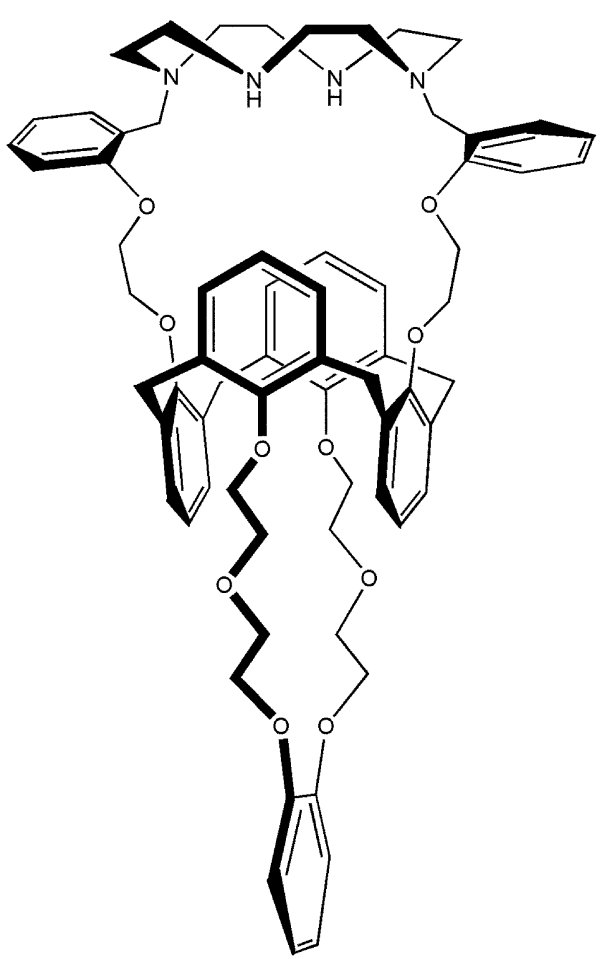

Figure 1. Structure of calix [4]-cyc]en-benzo-crown-6.

of the receptor $\mathbf{L}$ were determined by means of potentiometric titrations. Concentrations of free hydrogen ion $\left[\mathrm{H}^{\circ}\right]$ in the solution were measured by a combined electrode (Mettler DG 113-SC) connected to an automatic titrator (Mettler DL 25) at $25^{\circ} \mathrm{C}$. The electrode was calibrated at $\mathrm{pH}$ -2.0 with a standard solution of $1.00 \times 10^{-2} \mathrm{M} \mathrm{HClO}_{4}$ by adjusting the Nernstian slope based on the isopotential point of $\mathrm{pH} 8.30-0.0 \mathrm{mV}$. According to the junction potentials of the electrode, the $\mathrm{pH}$ of the solution can be corrected by using the following formula. . $^{\text {s }}$ 


$$
\mathrm{pH}_{\text {correcled }}=\mathrm{pH}_{\text {obserzed }}+\mathrm{a}-\mathrm{b}\left[\mathrm{H}^{-}\right]_{\text {olseris ed }}
$$

The constants $a$ and $b$ were determined from the $\mathrm{pH}$ measurements of the solutions of $1.00 \times 10^{-3} \mathrm{M} \mathrm{HClO}_{4}$ and $1.00 \times 10^{-2} \mathrm{M} \mathrm{Bu} \mathrm{NCF}_{3} \mathrm{SO}_{3}$ prepared in $40 \% \mathrm{CH}_{2} \mathrm{Cl}_{2}$ $\mathrm{CH}_{3} \mathrm{OH}$. All potentiometric titrations were carried out at 25 ${ }^{\circ} \mathrm{C}$ with deviation of $\pm 0.1^{\circ} \mathrm{C}$, regulated by an external Heto DT-2 thermostat. The titrations were performed under argon atmosphere. Typically, $10 \mathrm{~mL}$ of the ligand solution was titrated with the $\mathrm{Bu}{ }_{4} \mathrm{NOH}$ solution in a temperaturecontrolled beaker. The ligand concentration was varied from $9.00 \times 10^{-1} \mathrm{M}$ to $9.70 \times 10^{-1} \mathrm{M}$. At least 40 points of each potentiometric titration were used in computations for the equilibrium constants. Protonation constants of the receptor $\mathrm{L}$ were refined using the SUPERQUAD ${ }^{17}$ program.

The 1,3-alternate calix[4]-cyclen-benzo-crown-6, receptor L was synthesized according to the reported procedure. ${ }^{18}$ The solution of the electrolyte was obtained by dissolution of a weighed quantity of $\mathrm{Bu}_{4} \mathrm{NCF}_{3} \mathrm{SO}_{3}$ (Fluka) in $40 \%$ $\mathrm{CH}_{2} \mathrm{Cl}_{2} / \mathrm{CH}_{3} \mathrm{OH}$. The ionic strength was kept at $1.00 \times 10^{-2}$ $M$ for all experiments. The solution of receptors $L(1.00 \times$ $\left.10^{-3} \mathrm{M}\right)$ and their corresponding titrant base, $\mathrm{B} \mathrm{u}_{4} \mathrm{NOH}(1.00$ $\times 10^{-2} \mathrm{M}$ ) were prepared in $40 \% \mathrm{CH}_{2} \mathrm{Cl}_{2} / \mathrm{CH}_{3} \mathrm{OH}, 1.00 \times$ $10^{-2} \mathrm{M} \mathrm{Bu} \mathrm{NCF}_{3} \mathrm{SO}_{3}$. A standard solution of $\mathrm{HClO}_{4}(\mathrm{ca}$. $1.00 \times 10^{-2} \mathrm{M}$ ) in the background solution was used to adjust the $\mathrm{pH}$ of the working solution.

UV-VIS Spectrometric Measurements: The solutions of calix[4]-cyclen-benzo-crown-6 were prepared by dissolving the weighted quantities of receptor $\mathbf{L}$ in $1.00 \times 10^{-2} \mathrm{M}$ $\mathrm{Bu}_{4} \mathrm{NCF}_{3} \mathrm{SO}_{3}$ in $40 \% \quad \mathrm{CH}_{2} \mathrm{Cl}_{2} / \mathrm{CH}_{3} \mathrm{OH}$. The solutions of transition metal ions $\mathrm{Cu}^{2+}$ and $7 . \mathrm{n}^{2-}$ were prepared by dissolution of the weighted quantities of $\mathrm{Cu}\left(\mathrm{CF}_{3} \mathrm{SO}_{3}\right)_{2}$ and $\mathrm{Zn}\left(\mathrm{CF}_{3} \mathrm{SO}_{3}\right)_{2}$ in $1.00 \times 10^{-2} \mathrm{M} \mathrm{Bu} \mathrm{NCF}_{3} \mathrm{SO}_{3}$ in $40 \%$ $\mathrm{CH}_{2} \mathrm{Cl}_{2} / \mathrm{CH}_{3} \mathrm{OH}$, respectively. As working solution. $3.00 \mathrm{~cm}^{3}$ of receptor $\mathbf{L}$ in $1.00 \times 10^{-2} \mathrm{M} \mathrm{Bu}_{4} \mathrm{NCF}_{3} \mathrm{SO}_{3}$ in $40 \% \mathrm{CH}_{2} \mathrm{Cl}_{2}$ $\mathrm{CH}_{3} \mathrm{OH}$ solution was placed in UV-VIS titrating cell (cuvet size ca. $4 \mathrm{~cm}^{3}$ ). UV-VIS spectrometric titrations were recorded against the supporting electrolyte. The titrations were performed at $25^{\circ} \mathrm{C}$. Metal ion solution $0.05 \mathrm{~cm}^{3}$ was added for each titration step using a micro syringe of size $2.00 \mathrm{~cm}^{3}$, GS-1200, Gilmont (connected with capillary Jeflon tube). At least ten titration steps were performed and UV-VIS absorbances of titrating solutions were recorded within the range of 200 to $400 \mathrm{~mm}$. Absorbance data recollected from the whole range of UV-VIS spectra stepping by 10 to $20 \mathrm{~nm}$ were used in evaluation process for determination of stability constant of complex using the SIRKO program. ${ }^{19}$

\section{Ab initio Calculations Section}

Most stable structure of receptor $\mathbf{L}$ and its zinc complex were carried out by geometry optimization using semiempirical AMI method. ${ }^{20}$ The single-point energies of the optimized geometries of receptor $\mathbf{L}$ computed by $a b$ initio calculations with $\mathrm{Hr} / 6-31 \mathrm{G}^{21-2.3}$ methods were obtained. The complexation energy of $\mathrm{ZnL}$ were derived
Table I. Protonation constants of calix $|4|-c y c l e n-b e n z o-c r o w n-6$. receptor $\mathbf{L}$ in $1.00 \times 10^{-2} \mathrm{M} \mathrm{Bu}_{4} \mathrm{NCF}_{3} \mathrm{SO}_{3}$ in $40 \% \mathrm{CH}_{2} \mathrm{Cl}_{2} / \mathrm{CH}_{3} \mathrm{OH}$ at $25^{\circ} \mathrm{C}$

\begin{tabular}{|c|c|c|c|c|c|c|}
\hline \multicolumn{6}{|c|}{ Protonation } & \multirow{2}{*}{$\frac{\log K}{10.91 \pm 0.13}$} \\
\hline $\mathrm{K}_{1}$ & : & $\mathbf{L}$ & $\mathrm{H}^{-}$ & 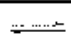 & $\mathbf{L H}^{+}$ & \\
\hline $\mathrm{K}_{2}$ & : & $\mathbf{L H} H^{-}$ & $+\mathrm{H}^{-}$ & $=$ & $\mathbf{L H}_{2}{ }^{2+}$ & $10.30 \pm 0.25$ \\
\hline $\mathrm{K}_{3}$ & & $\mathbf{L H}_{2}{ }^{2-}$ & $+\mathrm{H}^{-}$ & $=$ & $\mathbf{L H}_{s}{ }^{3+}$ & $6.24 \pm 0.26$ \\
\hline $\mathrm{K}_{4}$ & : & $\mathbf{L H}_{3}{ }^{\mathbf{-}}$ & $+\mathrm{H}^{-}$ & $\ldots \ldots .$. & $\mathbf{L H}_{4}{ }^{1+}$ & $2.55 \pm 0.28$ \\
\hline
\end{tabular}

from the $\mathrm{HF} / 6-31 \mathrm{G}$ energies of its related species. All calculations were performed with Gaussian 03 program. ${ }^{2 \cdot 1}$

\section{Results and Discussion}

Protonation constants of the calix[4]-cyclen-benzo-crown6, receptor $\mathrm{L}$ in $1.00 \times 10^{-2} \mathrm{M} \mathrm{Bu}_{4} \mathrm{NCF}_{3} \mathrm{SO}_{3}$ in $40 \% \mathrm{CH}_{2} \mathrm{Cl}_{2}$ / $\mathrm{CH}_{3} \mathrm{OH}$ at $25^{\circ} \mathrm{C}$ are shown in Table 1. First and second protonation constants expressed as $\log \mathrm{K}_{1}$ and $\log \mathrm{K}_{2}$ are approximately same magnitude (10.91 and 10.30 , respectively) but obviously different from third and fourth protonation constants $\left(\log \mathrm{K}_{3}\right.$ and $\left.\log \mathrm{K}_{4}\right)$. The first two and second two protonation constants correspond to the protonations according to the two secondary-amine and two tertiary-amine nitrogen atoms of the receptor $\mathbf{L}$, respectively. Distribution curves species of the receptor $\mathbf{L}$ in $40 \% \mathrm{CH}_{2} \mathrm{Cl}_{2}$ / $\mathrm{CH}_{3} \mathrm{OH}$ at $25^{\circ} \mathrm{C}, \mathrm{C}_{\mathrm{L}}=9.10 \times 10^{-3} \mathrm{M}$ are shown in Figure 2 . The species distribution curves show that the $\mathrm{LH}_{4}{ }^{1+}$ species is steeply decreased from around $30 \%$ mol at $\mathrm{pH} 2.6$ to less than $5 \%$ at $\mathrm{pH}$ higher than 4.0 . Over $70 \%$ of the $\mathbf{L H}_{3}{ }^{3-}$ species exists within the $\mathrm{pH}$ range of 3.1 to 5.8 . The $\mathrm{LH}_{2}{ }^{2-}$ species appears at $\mathrm{pH} 8.3(\sim 97 \%)$. The $\mathrm{LH}^{+}$species exists within the $\mathrm{pH}$ range of 8.3 to $\sim 11$. The maximum population of $\mathrm{LH}^{-}$species appears at $\mathrm{pH} 10.6(\sim-50 \%)$. The free ligand species, $\mathbf{L}$ exists at $\mathrm{pH}$ higher than -9.5 and its highest population is steeply increased at higher $\mathrm{pH}$. The present species of $\mathbf{L}$ in $1.00 \times 10^{-2} \mathrm{M} \mathrm{Bu}_{4} \mathrm{NCF}_{3} \mathrm{SO}_{3}$ in $40 \% \mathrm{CH}_{2} \mathrm{Cl}_{2}$ ? $\mathrm{CH}_{3} \mathrm{OH}$ depend on $\mathrm{pH}$ of solution as shown in lable 2. Stability constants of the complex $\mathbf{L}$ with $\mathrm{Cu}(\mathrm{Il})$ and $\mathrm{Zn}(\mathrm{Il})$

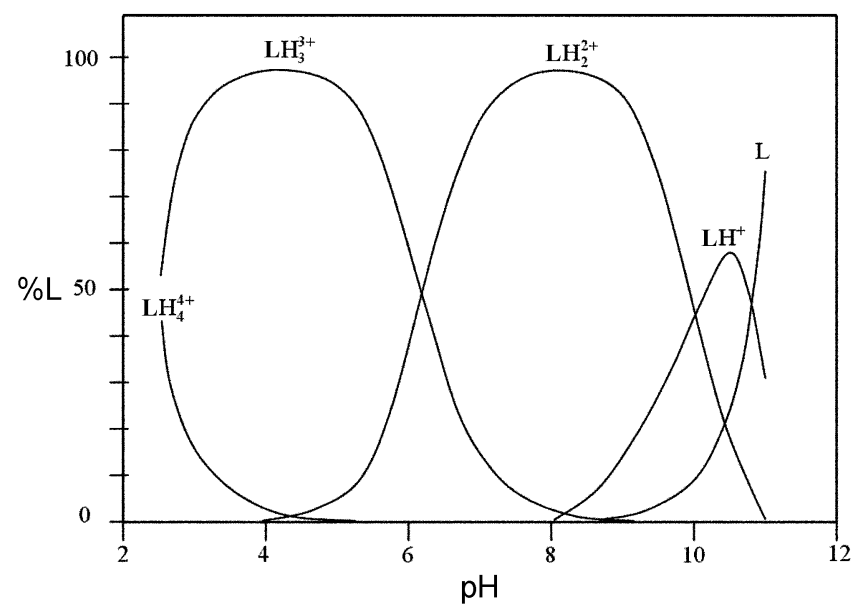

Figure 2, Distribution curves species of the receptor I. in $40 \%$ $\mathrm{CH}_{2} \mathrm{Cl}_{2} / \mathrm{CH}_{3} \mathrm{OH}$ at $25^{\circ} \mathrm{C} . \mathrm{CL}=9.10 \times 10^{-3} \mathrm{M}$. 
Table 2. ['redominant species of calix[4]-cyclen-henzo-crown-6. L in $1.00 \times 10^{-2} \mathrm{M} \mathrm{Bu}_{4} \mathrm{NCF}_{3} \mathrm{SO}_{3}$ in $40 \% \mathrm{CH}_{2} \mathrm{Cl}_{2} \mathrm{Cll}_{3} \mathrm{Oll}$ at $25^{\circ} \mathrm{C}$. depending on the pH of solution

\begin{tabular}{cc}
\hline Predominant species & $\mathrm{pH}$ ranges \\
\hline $\mathbf{L}$ & $>-99$ \\
$\mathbf{L H}^{+}$ & 8.3 to $-\cdots 11$ \\
$\mathrm{LH}_{2}^{2-}$ & $400-11$ \\
$\mathrm{LH}_{3}^{3-}$ & $-310-8.3$ \\
$\mathrm{LH}_{4}^{+-}$ & $<-4.5$ \\
\hline
\end{tabular}

Table 3. Stability constants ( $\log \beta$ ) of $\mathrm{CuL}$ and $\mathrm{ZnL}$ complexes in $1.00 \times 10^{-2} \mathrm{M} \mathrm{Bu}_{4} \mathrm{NCF}_{3} \mathrm{SO}_{3}$ in $40 \% \mathrm{CH}_{2} \mathrm{C}_{2} \mathrm{CH}_{3} \mathrm{OH}$ at $25^{\circ} \mathrm{C}$.

\begin{tabular}{cc}
\hline Complexes & $\log \beta$ \\
\hline $\mathrm{CuL}^{2+}$ & $4.37 \pm 0.005$ \\
$\mathrm{ZnL}^{2-}$ & $3.45 \pm 0.005$ \\
\hline
\end{tabular}

Table 4. Protonation cncrgies of the calix[4]-cyclen-benzo-crown6. L and stabilization energy of its zinc complex derived from the IIF/6-3IGì melhod

\begin{tabular}{|c|c|c|c|c|c|c|c|}
\hline \multicolumn{7}{|c|}{ Retacions } & $\begin{array}{c}\text { P'rotonation sncroiss } \\
\text { (kcal/mol) }\end{array}$ \\
\hline$\Delta \mathrm{r}_{1}$ & : & L & 1 & $\mathrm{HI}^{\prime}$ & $=$ & LJ I" & -290.1 \\
\hline$\Delta \mathrm{r}_{2}$ & : & $\mathrm{LHI}^{+}$ & 1 & $\mathrm{HI}^{*}$ & $=$ & LIts" & -205.0 \\
\hline$\Delta \mathrm{r}_{3}$ & : & $\mathrm{LH}_{2}^{2}$ & 1 & $\mathrm{HI}^{\circ}$ & $=$ & $\mathbf{L H} \mathbf{H}^{2}=$ & -124.9 \\
\hline$\Delta \mathrm{r}_{4}$ & & $\mathrm{LH}_{3}{ }^{\mathrm{t}}$ & 1 & $\mathrm{H}^{\prime}$ & $=$ & $\mathrm{LIL}^{4+}$ & -26.9 \\
\hline$\Delta \mathrm{r}_{\text {iomplex }}$ & & 1. & 1 & $y n^{2}$ & $\Longrightarrow$ & $/ \mathrm{nL}^{*}$ & -370.3 \\
\hline
\end{tabular}

in $1.00 \times 10^{-2} \mathrm{M} \mathrm{Bu}_{4} \mathrm{NCF}_{3} \mathrm{SO}_{3}$ in $40 \% \mathrm{CH}_{2} \mathrm{Cl}_{2} / \mathrm{CH}_{3} \mathrm{OH}$ at 25 ${ }^{\circ} \mathrm{C}$, in terms of $\log b$ are shown in Table 3. The receptor $\mathbf{L}$ seems to form strong complex with $\mathrm{Cu}^{2-}$ rather than $7 \mathrm{n}^{2+}$ ions.

Protonation energies of the calix[4]-cyclen-benzo-crown6. L and stabilization energy of its zinc complex derived from the HF/6-31G method are listed in Table 4. The protonation energies of receptor $\mathbf{L}$ have been investigated with respect to their relation to the corresponding protonation constants as shown in Figure 3 . The protonation energy,

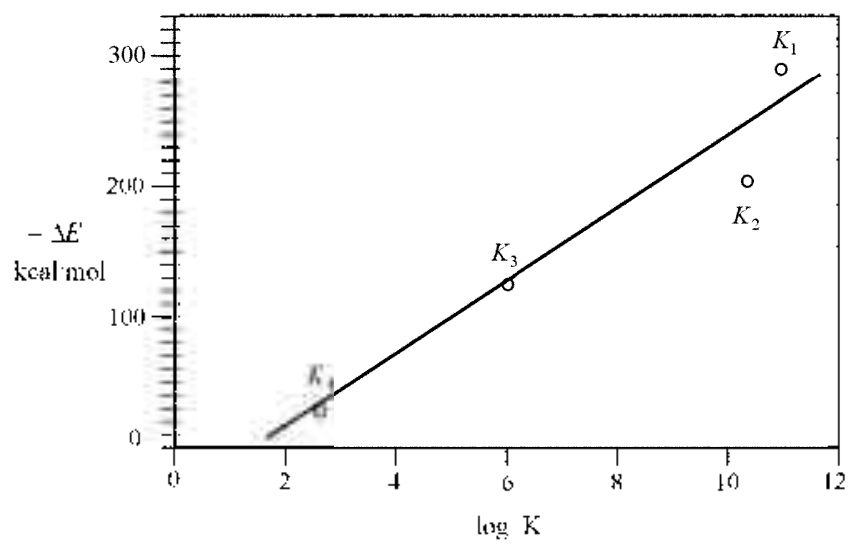

Figure 3. Correlation between protonation energies of the receptor $\mathbf{L}$ and their corresponding $\log \mathrm{K}$.

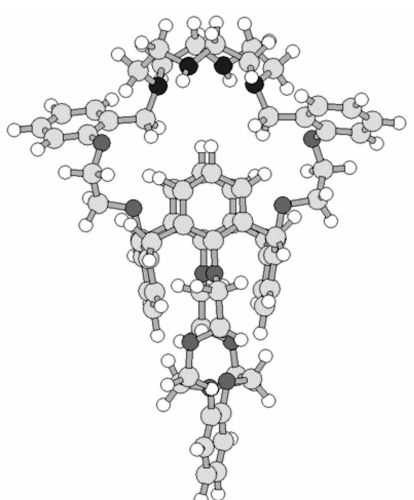

(a)

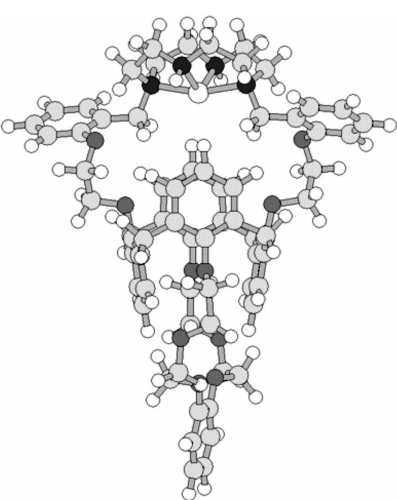

(b)
Figure 4. AMI optimized structures of (a) calix[4]-cyclen-benzowoun-6 and (b) its zinc complex.

$\Delta \Gamma$ is closely related to the reaction enthalpy $\Delta H\left\langle\Delta \Gamma_{c}=\Delta \mathrm{H}\right.$ $\mathrm{P} \Delta \mathrm{V}$ ). As volume changes in the system can be expected to very small, the protonation energy of the system will nearly equal to the reaction enthalpy. The logarithm of the equilibrium constant is partly dependent on the enthalpy $(\Delta \mathrm{H}=\Delta \mathrm{G}+\mathrm{T} \Delta \mathrm{S}$ and $\Delta \mathrm{G}=-2.302 \mathrm{RT} \log \mathrm{K})$. The relation between the protonation energies and their corresponding $\log K$ could be linear, therefore, if $\Delta S$ and solvation contribution to $\Delta \mathrm{H}$ were constant for all protonation processes. A tendency towards such a linear correlation between computed protonation energies and corresponding $\log \mathrm{K}$ of this system cannot be recognized as shown in Figure 3. This result is probably caused by the differences in $\Delta \mathrm{S}$ and also from the calculation without hydration model.

Structure of the calix[4]-cyclen-benzo-crown-6 and its zinc complex obtained with the AM1 optimization method are shown in Figure 4. As four donor nitrogen atoms of receptor $\mathbf{L}$ coordinate to a zinc ion, distorted tetraluedral geometry of the $7 \mathrm{~nL}$ complex is presented as shown in Figure 4(b). This complex geometry agrees with tetrahedral geometry of $\left[\mathrm{Kn}\left(\mathrm{NH}_{3}\right)_{4}\right]^{2+}$.

\section{Conclusions}

The protonation constants of calix[4]-cyclen-benzo-crown6 in $1 \times 10^{-2} \mathrm{M} \mathrm{Bu}_{4} \mathrm{NCF}_{3} \mathrm{SO}_{3}$ in $40 \% \mathrm{CH}_{2} \mathrm{Cl}_{2} / \mathrm{CH}_{3} \mathrm{OH}$ at 25 ${ }^{\circ} \mathrm{C}$ determined by potentiometric method are $\log \mathrm{K}_{1}=10.9 \mathrm{l}$, $\log K_{2}=10.30, \log K_{3}=6.24$ and $\log K_{4}=2.55$. The stability constants of the CuL and $Z n \mathbf{L}$ complexes, determined by UV-VIS spectrometric titration, as $\log \beta$ are 4.37 and 3.45 . respectively. The stabilization energies for protonation of

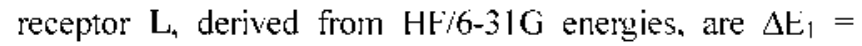
$-290.1, \Delta \mathrm{E}_{2}=-205.0, \Delta \mathrm{E}_{\hat{\mathrm{j}}}=-124.9$ and $\Delta \mathrm{E}_{4}=-26.9 \mathrm{kcal} / \mathrm{mol}$ and complexation energy of $\angle \mathrm{nL}$ complex is $-370.3 \mathrm{kcal} /$ mol.

Acknowledgments. This work was partly supported by the graduate school, Chulalongkorn University. We gratefully acknowledges the financial support from Rachadapisek Sompoch Endowment Fund, Chulalongkorn University and 
thank the Conunission on Higher Education, Ministry of Education for financial support to T.B. We also thank Ms. M. Jankratoke for her help on synthesis of the receptor $\mathbf{L}$.

\section{References}

1. (a) Shinkai. S. Tetratredron 1993, 49.8933, (b) Böhmer. V. Angew. Chem. Int. Ed. Engl. 1995, 34.713.

2. Lhoták, P. L: Shinkai, S. J. Sinth. Org Chent. Jpn. 1995. 53. 963.

3. Pochini. A.: Ungaro. R. In Comprehensive Supramolecthor Chemishy: Vögel. F. Ed.: Pergamon Press: 1996: p 103.

4. Ikeda. A.: Shinkai. S. Chem. Rev: 1997.97.1713.

5. McKervev: M. A.: Seward E. M. Ferguson. G.: Ruhl. B. L.: Harris. S. J. J. Chem. Soc. Chem. Commm. 1985, 388.

6. Chang, S. K: Kwon, S. K.: Cho. I. Chem. Leth 1987.947.

7. Ferguson. G.: Kaitner. B: McKervey. M. A.: Seward. E. M. J. Chem. Soc. Chem. Commm, 1987, 584

8. Ludwig. R.: Matsumoto. H.: Takeshita. M.: Ueda. K.: Shinkai. S. Siprantol. Chem. $1995,4319$.

9. Nagasaki. T.: Shinkai. S. J. Chent. Soc. Perkin Trans. 21991. 1063 .

10. Bottino. F.: Giunta. L.: Pappalardo. S. J. Org. Chem. 1989. 54. 5407.

11. Beer. P. D.: Martin. J. P.: Drew: M. G. B. Tetrahedron 1992. 48. 9917.

12. Matt D.: Loeber C.: Vicens, I.: Asfari. Z. J. Chent Soc. Chent. Conmmin. 1993, 604.

13. Arnaud-Neu. F.: Barrett. G.: Harris. S. J: Owens. M.: McKervey. M. A.: Schwing-Weill. M.-J.: Schwinte. P. horg. Chem. 1993. 32. 2644

14. Casnati. A.: Pochini. A.: Ungaro, R: Ugozzoli, F.: Arnauld-Neu, F: Fanni, S.: Schwing. M.J.: Egberink, R. I. M.: de Jong. F.: Reinhoudt. D. J.Am Chem. Soc. 1995, 117. 2767.

15. Annaud-Neu. F.: Collins. E. M.: Deasy. M.: Ferguson. G.: Harris. S. J.: Kaitner. B.: Lough. A. J.: McKervey. M. A.: Marques. E.: Ruhl. B. L.: Schwing-Weill. M.-I.: Seward. E. M. J. Am. Chem. Soc. 1989, HI. 8681 .

16. Amaud-Neu. F.: Cremin. S.: Harris. S: McKervey M. A.: Schwing-Weill, M.-I.; Schwinté, P.: Walker A. J. Chent. Soc.,
Dallon Trans. 1997. 329

17. Gan1s. P.: Sabatini. A.: Vacea. A. J. Chem. Soc. Dallon Trans. 1985.1195.

18. Pulpoka. B; Jamkratoke. M.; Tuntulani. T:; Ruangpornvisuti. V. Tetrahedron Lett. $\mathbf{2 0 0 0}$, 1.9167

19. Vetrogen. V.: Luhyamenko. N. G.: Schwing-Weill. M. J.: ArnaudNeu. F. Talanta 1994. 11.2105.

20. (a) Dewar. M. J. S.: Thiel. W. J. Am. Chem. Soc, 1977. 99. 4499 (b) Davis. L. P., Guidry, R. M.: Williams, J. R.: Dewar. M. J. S: Rzep. H. S. J. Comput. Chem. 1981, 2, 433. (c) Dewar. M. J. S: MeKee, M. L.; Rzepa. H. S. J. Am. Chem. Soc. 1978, 100, 3607. (d) Dewar. M. J. S.: Zoebisch. E. G.: Healy. E. F. J. Am. Chem. Soc. 1985. 107. 3902. (e) Dewar. M. T. S.: Reynolds. C. H. $J$. Comput. Chem. 1986. 2. 140.

21. (a) Ditchfield. R; Hehre. W. J ; Pople. J. A. J. Chem. Phns 1971. 54. 724. (b) Hehre, W. J.; Ditchifield, R; Pople. J. A. J. Chen Phis. 1972, 56,2257.

22. (a) Hariharan. P. C.: Pople. J. A. Theo. Chim Acta 1973. 28. 213 (b) Hariharan. P. C.: Pople. T. A. J. M fol Phvs. 1974. 27. 209.

23. Gordont. M. S. Chem. Phus. Lett 1980. 76. 163.

24. Frisch. M. J:- Trucks. G. W: Schlegel, H. B.: Scuseria. G. E.; Robb. M. A.; Cheeseman, J. R.; Montgomery. J. A.; Vreven, Jr. T: Kudin, K. N.: Burant, J. C.: Millam, J. M.; Iyengar. S. S.; Tomasi. J.: Barone. V: Mentucei. B.: Cossi. M.: Scalnnani. G.: Rega. N.: Petersson. G. A.: Nakatsuji. H.: Hada. M.: Ehara. M.: Toyota. K.: Fukuda. R.: Hasegawa. T.: Ishida. M.: Nakajima. T: Honda. Y: Kitao. O.: Nakai. H.; Klene, M.: Li. X: Knox, J. E: Hratchian. H P. Cross, J. B.; Adamo. C.: Jaramillo. J: Gomperts. R: Stratmann, R. E.: Yazyev, O.: Austin. A. J.: Cammi, R.: Pomelli. C.: Ochterski. J. W: Ayala. P. Y: Morokuma. K: Voth. G. A.: Salvador. P.: Dannenberg. I. J.: Zakizewski. V. G.: Dapprich. S.: Daniels. A. D.: Strain. M. C.: Farkas. O.: Malick. D. K.: Rabuck. A. D.: Raghavachari, K.: Foresman, J. B.; Ortiz. J. V: Cui. Q: Baboul. A. G.; Clifford, S.; Cioslowski. J.; Stefanov, B. B.: Liu. G.; Liashenko, A.: Piskorz, P.: Komaromi, I; Martin. R. L.: Fox. D. J: Keith. T.: Al-Laham. M. A.: Peng. C. Y.: Nanayakkara. A.: Challacombe M.: Gill. P. M. W.: John1son1. B.: Chen. W.: Wong. M. W.: Gonzalez. C.: Pople. J. A. Gaussian 03. Revision B.03: Gaussian. Inc.: Pittsburgh. PA, 2003.

25. Brown, T. L.; LeMay. H. E., Jr.: Bursten. B. E. Chemistry the Central Science; Pentice-Hall: New Jersey. 1997: p 903. 